\title{
Cancer and occupational exposure to pesticides: an umbrella review
}

\author{
Carol J. Burns ${ }^{1} \mathbb{D} \cdot$ Daland R. Juberg ${ }^{2}$
}

Received: 28 July 2020 / Accepted: 17 December 2020 / Published online: 25 January 2021

(c) The Author(s) 2021

\begin{abstract}
Purpose The aim was to identify the scope of the epidemiology literature reviewed regarding the risk of cancer as related to occupational exposure to pesticides and to compare regulatory toxicity results where feasible.

Methods Review studies of breast, lung, prostate, non-Hodgkin lymphoma, and colorectal cancer were identified from the published literature from 2010 to 2020 using a priori inclusion and exclusion criteria. Epidemiology observations were first assessed and then compared against carcinogenicity profiles derived from regulatory toxicology studies.

Results Several active ingredients were associated with specific cancer but overall, there was neither strong nor consistent epidemiologic data supportive of a positive association between pesticide exposure in occupational settings and cancer. Authors noted common themes related to the heterogeneity of exposure, study design, control for confounders, and the challenge to collect these data reliably and validly with an adequate sample size. Toxicology studies in laboratory animals that assessed carcinogenic potential did not reveal cancer outcomes that were concordant with reported epidemiologic findings. Conclusions Farming and pesticides represent diverse exposures that are difficult to quantify in epidemiologic studies. Going forward, investigators will need creative and novel approaches for exposure assessment. Integration of epidemiologic and toxicological studies with attention to biological plausibility, mode of toxicological action and relevance to humans will increase the ability to better assess associations between pesticides and cancer.
\end{abstract}

Keywords Pesticides $\cdot$ Epidemiology $\cdot$ Cancer $\cdot$ Farming $\cdot$ Toxicology

\section{Introduction}

Cancer etiology has been studied for decades to characterize risk factors such as genetic predisposition, lifestyle, and environmental factors, the latter with particular focus on chemical agents, including pesticides. Generally recognized modifiable risk factors for cancer are related to behavior and diet, including smoking, alcohol consumption, unhealthy diet, obesity, insufficient physical activity, and certain infections (World Health Organization 2018). Given the prevalence and use of agricultural chemicals in farming, it is important to seek clarity on whether occupational

\footnotetext{
Supplementary Information The online version contains supplementary material available at https://doi.org/10.1007/s0042 0-020-01638-y.
}

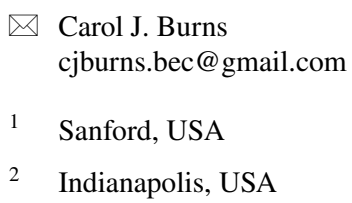

Carol J. Burns

cjburns.bec@gmail.com

1 Sanford, USA

2 Indianapolis, USA

exposure to pesticides is an independent risk factor for cancer. Because pesticides are evaluated for carcinogenicity in laboratory animals as a part of regulatory requirements, it is also relevant to understand the outcomes of this testing and how it may inform putative associations between cancer and pesticides in humans. These studies are conducted not only for evaluation of intrinsic carcinogenic potential in an animal model but also for determination of relevance to humans and cancer classification and labeling purposes.

The U.S. National Cancer Institute (NCI) and the European Food Safety Authority (EFSA) published reviews of the cancer burden related to pesticide exposure in 2012 and 2013 (Alavanja and Bonner 2012; Alavanja et al. 2013; Ntzani et al. 2013). The EFSA-sponsored reviewers noted that while there were many epidemiologic studies, there were limitations to drawing conclusions (Ntzani et al. 2013). The NCI reviewers suggested "substantial risks" and recommended multidisciplinary efforts to improve the scientific understanding (Alavanja and Bonner 2012; Alavanja et al. 2013). Evaluations of selected active ingredients were also recently evaluated and reported by the International Agency 
for Research on Cancer (IARC) (2017, 2018, 2019). Lindane was the only pesticide determined to be carcinogenic based upon sufficient data in both humans and animals. The epidemiology evidence for other pesticides reviewed was considered to be limited or inadequate.

To provide a more multidisciplinary view, the aim of this review was to identify the scope of the epidemiology literature reviewed, i.e. a review of reviews, in the past decade regarding the risk of cancer as related to occupational exposure to pesticides and to compare the conclusions from regulatory cancer bioassays in animals where feasible for pesticides and cancer. The objectives were to evaluate: (1) the evidence within epidemiologic literature of farmers and other agricultural workers exposed to pesticides and the association with cancer of the lung, breast, colorectum, prostate, and non-Hodgkin lymphoma (NHL) and (2) whether there is consistent and supportive evidence and biological plausibility for these cancer types from animal toxicology studies.

\section{Methods}

A review of qualitative and quantitative reviews was undertaken following the recommendations of Aromataris et al. (2015) and with consideration for systematic review evaluation in general (Shea et al. 2017; Moher et al. 2009). Each step of the process was performed independently by both authors, with stepwise discussion to clarify and resolve any disagreements.

The literature search was focused upon reviews of epidemiologic studies of globally prevalent cancers of lung, prostate, colorectal, breast and NHL and occupational exposure to pesticides published in the last 10 years (e.g. (Arnold et al. 2015; Blair et al. 1992; IARC 2020b)). This time period was selected to bound the reviewable literature from the 2012 and 2013 reviews (Alavanja and Bonner 2012; Alavanja et al. 2013; Ntzani et al. 2013) and to capture recently reviewed studies. PubMed and Web of Science databases were searched in January 2020. The search strategy was: (cancer or neoplasm or tumor) and human and (pesticide or herbicide or insecticide or fungicide or farm) and (metaanalysis or systematic review or review), allowing for truncation of words and MESH terms. Both searches were limited to peer reviewed English-language publications from 2010 to 2020 . The search was not restricted to study design, cancer mortality or incidence, or use of systematic approaches. Editorials were not included. Also excluded were reviews specific to other cancers, children, general populations, a focus upon exposure without health endpoints and studies of animals. Reviews of dioxins were excluded as they are contaminants and not a specific active ingredient.
The IARC monographs from this period were used to identify published meta-analyses of one or more pesticides. The PRISMA flowchart is shown in Fig. 1. After removing duplicates, a total of 519 publications were identified. Screening based on titles and abstracts narrowed the number of reviews to 84 publications based upon the criteria above. The full text of these 84 studies was reviewed by both authors and attenuated to 30 primary publications, excluding editorials, publications on other cancers or not of epidemiology. Aspects of each study were recorded. These included stated study objectives, databases searched, data range of search, inclusion and exclusion criteria provided, number of studies reviewed, number of studies that were from a single source (Agricultural Health Study, AHS), instrument(s) used to assess quality, number of studies that were occupational, and approaches to the weight of evidence interpretation.

\section{Results: epidemiology}

We identified 30 review publications that met the inclusion criteria (Table 1). More than half of the reviews focused upon one type of cancer and many concentrated upon a specific pesticide. The number of reviewed studies was reflective of the scope of the review. For example, reviewers evaluated more than 100 studies in two publications of all cancers (Alavanja and Bonner 2012; Ntzani et al. 2013) while there were only five studies included in the review of methyl bromide and prostate cancer (Budnik et al. 2012). Most reviewers provided information consistent with systematic review processes such as databases searched, data range of the search, and inclusion and exclusion criteria, with a few exceptions (Alavanja et al. 2013; Boffetta et al. 2013; Jowa and Howd 2011). The number of AHS studies per review reflects the considerable number of publications from this single cohort study of farmer applicators in the United States. Approximately half of the reviewers incorporated a quality assessment of each reviewed study. Many used the Newcastle Ottawa Scale (NOS), two used the Effective Public Health Practice Project (EPHPP), while others evaluated study quality using their own list of elements.

\section{Breast, lung and colorectal cancers}

There were few reviews that addressed breast, lung and/ or colorectal cancers and all were qualitative, i.e. narrative reviews. Ntzani et al. (2013) discussed epidemiologic study results for breast, colorectal, and lung cancers, concluding that for the most part, the evidence was limited and inconclusive. Boffetta et al. also discussed a lack of association with pesticide exposure and breast cancer in the reviews of permethrin (Boffetta and Desai 2018) and atrazine (Boffetta 
Fig. 1 PRISMA 2009 flow diagram

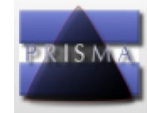

\section{PRISMA 2009 Flow Diagram}
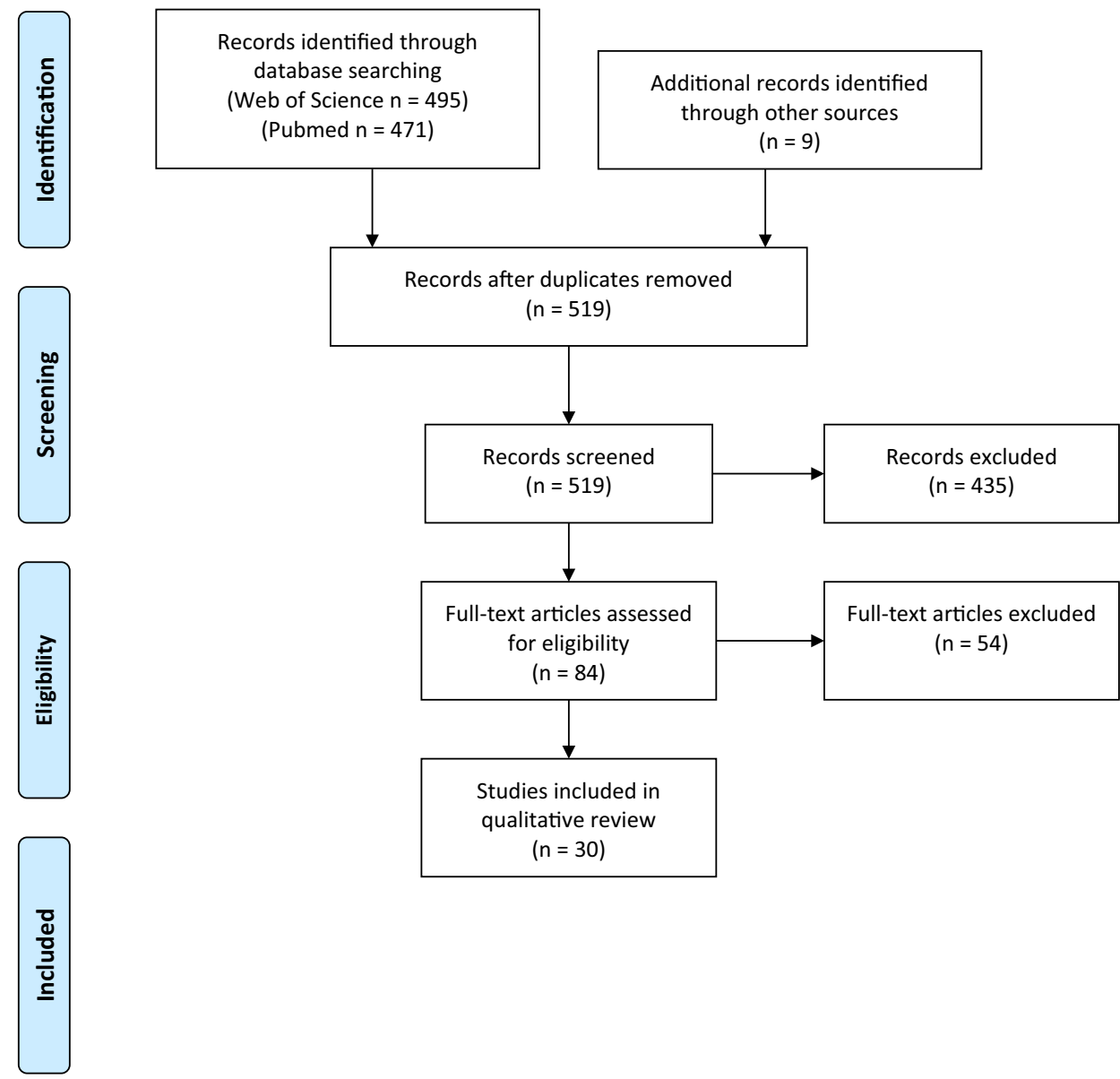

et al. 2013). Two reviews focused upon colorectal cancer with neither indicating an increased risk for any pesticide (Alexander et al. 2012; Oddone et al. 2014). In their reviews of triazine herbicides, Jowa and Howd characterized the epidemiologic data as being inadequate for cancers of breast and colon (Jowa and Howd 2011). Sathiakumar et al. discussed results of a single case-control study of colon cancer for which odds ratios differed by comparison group $(\mathrm{OR}=1.4$ compared with nonfarmers and OR $=0.6$ compared with farmers who had not used triazines) (Sathiakumar et al. 2011).

\section{Prostate cancer}

Fourteen reviews assessed the association of prostate cancer and exposure to pesticides and/or farming. As shown in Table A1 in the Appendix these publications varied in their focus (general vs. specific pesticides) and approach (qualitative vs. quantitative). The reviewers of several specific active ingredients (i.e., 2,4-D, atrazine, and organophosphates) reported no significant associations between exposure and prostate cancer (Boffetta et al. 2013; Goodman et al. 2015; Jowa and Howd 2011; Krstev and Knutsson 2019), while the review of methyl bromide was suggestive of an association based on a meta-analysis of three studies (meta Odds Ratio, mOR 1.21; 95\% CI 0.98-1.49) (Budnik et al. 2012). The association of organochlorines as a group and individually was evaluated by several reviewers (Krstev and Knutsson 2019; Lewis-Mikhael et al. 2015, 2016; Ntzani et al. 2013). Statistically significant associations were reported for organochlorines, collectively, based on 17 studies in Krestev et al. (2019) (meta Relative Risk, mRR 1.08, 95\% CI 1.03-1.14,) and eight studies in LewisMikhael et al. (2016) $(\mathrm{mRR}=1.35,95 \%$ CI 1.02-1.67).

Several reviewers evaluated studies with nonspecific exposure to pesticides and/or farming. Authors noted common themes related to the heterogeneity of exposure, 
Table 1 Reviews of cancer and pesticides

\begin{tabular}{|c|c|c|c|c|c|c|c|c|}
\hline $\begin{array}{l}\text { First author } \\
\text { (Year) }\end{array}$ & Cancer type & Exposure & $\begin{array}{l}\text { N Search } \\
\text { databases }\end{array}$ & $\begin{array}{l}\text { Inclusion/ } \\
\text { exclusion } \\
\text { criteria }\end{array}$ & Date range & $\mathrm{N}$ studies & $\mathrm{N}$ of AHS & $\begin{array}{l}\text { Quality } \\
\text { instrument }\end{array}$ \\
\hline $\begin{array}{c}\text { Alavanja } \\
\text { (2013) }\end{array}$ & All & Pesticides & NR & NR & NR & NR & NR & None \\
\hline $\begin{array}{c}\text { Alavanja } \\
\text { (2012) }\end{array}$ & All & Pesticides & 1 & $\mathrm{Y}$ & 1990-2010 & $103 *$ & NR & None \\
\hline Boffetta (2013) & All & Atrazine & NR & NR & NR & NR & NR & None \\
\hline Boffetta (2018) & All & Permethrin & 3 & Y & $x-2017$ & 18 & 11 & None \\
\hline Burns (2012) & All & $2,4-\mathrm{D}$ & $>3$ & $\mathrm{Y}$ & 2000-2012 & $27 *$ & 0 & None \\
\hline Jowa (2011) & All & $\begin{array}{l}\text { Atrazine ( } \& \\
\text { related chlo- } \\
\text { rotriazines) }\end{array}$ & NR & NR & NR & $25^{*}$ & 2 & None \\
\hline Mink (2012) & All & Glyphosate & 3 & NR & NR & 21 & 7 & None \\
\hline Nguyen (2018) & All & Pesticides & $>3$ & $\mathrm{Y}$ & $1990-2015$ & 5 & 5 & ЕРНPP \\
\hline Ntzani (2013) & All & Pesticides & $>3$ & $\mathrm{Y}$ & $2006-2012$ & 164 & 30 & Own \\
\hline $\begin{array}{l}\text { Sathiakumar } \\
\text { (2011) }\end{array}$ & All & $\begin{array}{l}\text { Triazine herbi- } \\
\text { cides }\end{array}$ & 3 & NR & NR & 36 & 4 & Own \\
\hline $\begin{array}{l}\text { Von Stackel- } \\
\text { berg (2013) }\end{array}$ & All & 2,4-D, MCPA & 3 & NR & NR & $41 *$ & 0 & None \\
\hline $\begin{array}{l}\text { Alexander } \\
(2012)\end{array}$ & Colorectal & Pesticides & 1 & $\mathrm{Y}$ & $x-2010$ & 42 & 29 & Own \\
\hline Oddone (2014) & Colorectal & Pesticides & 2 & $\mathrm{Y}$ & 1960-2013 & $\begin{array}{l}83 \text { (12 of } \\
\text { farming) }\end{array}$ & NR & None \\
\hline $\begin{array}{l}\text { Acquavella } \\
\text { (2016) }\end{array}$ & NHL & Glyphosate & 2 & $\mathrm{Y}$ & $x-2015$ & 16 & 1 & Own \\
\hline Chang (2016) & NHL & Glyphosate & 3 & $\mathrm{Y}$ & NR & 12 & 1 & Own \\
\hline $\begin{array}{l}\text { Goodman } \\
\text { (2015) }\end{array}$ & NHL, Prostate & $2,4-\mathrm{D}$ & 3 & $\mathrm{Y}$ & $x-2014$ & 11 & 0 & Own \\
\hline $\begin{array}{l}\text { Goodman } \\
\text { (2017) }\end{array}$ & NHL & $2,4-\mathrm{D}$ & $\begin{array}{l}\text { Update to } \\
2015\end{array}$ & $\begin{array}{l}\text { Per Goodman } \\
\quad 2015\end{array}$ & $\begin{array}{l}\text { Per Goodman } \\
\quad 2015\end{array}$ & 10 & 1 & Own \\
\hline $\mathrm{Hu}(2017)$ & NHL & $\begin{array}{l}\text { Organophos- } \\
\text { phates }\end{array}$ & 2 & $\mathrm{Y}$ & 1985-2017 & 10 & 5 & NOS \\
\hline $\begin{array}{c}\text { Jayakody } \\
(2015)\end{array}$ & NHL & Phenoxy & 2 & NR & $x-2014$ & 43 & 0 & None \\
\hline $\begin{array}{r}\text { Schinasi } \\
(2014)\end{array}$ & NHL & Pesticides & 2 & $\mathrm{Y}$ & 1980-2014 & 44 & 16 & None \\
\hline Smith (2017) & NHL & 2,4-D & 3 & $\mathrm{Y}$ & $x-2016$ & 12 & 0 & NOS \\
\hline Zhang (2019) & NHL & Glyphosate & $>3$ & $\mathrm{Y}$ & NR & 7 & 2 & NOS \\
\hline Budnik (2012) & Prostate & $\begin{array}{l}\text { Methyl bro- } \\
\text { mide }\end{array}$ & 1 & $\mathrm{Y}$ & 1990-2011 & 5 & 2 & None \\
\hline $\begin{array}{l}\text { Depczynski } \\
\text { (2014) }\end{array}$ & Prostate & $\begin{array}{c}\text { Pesticides, } \\
\text { farming }\end{array}$ & $>3$ & $\mathrm{Y}$ & 2002-2013 & 18 & 1 & EPHPP \\
\hline Doolan (2014) & Prostate & $\begin{array}{c}\text { Pesticides, } \\
\text { farming }\end{array}$ & 2 & NR & 2000-2012 & $28 *$ & NR & None \\
\hline Krstev (2019) & Prostate & $\begin{array}{c}\text { Pesticides, } \\
\text { farming }\end{array}$ & 2 & Y & $1966-2015$ & $\begin{array}{l}18 \text { pesticides, } \\
26 \text { farming }\end{array}$ & 1 & None \\
\hline $\begin{array}{l}\text { Lewis-Mikhael } \\
\text { (2016) }\end{array}$ & Prostate & Pesticides & 3 & $\mathrm{Y}$ & 1985-2014 & 52 & 21 & NOS \\
\hline $\begin{array}{l}\text { Lewis-Mikhael } \\
\text { (2015) }\end{array}$ & Prostate & $\begin{array}{l}\text { Organochlo- } \\
\text { rine }\end{array}$ & 3 & $\mathrm{Y}$ & $x-2015$ & 15 & 1 & NOS \\
\hline Ragin (2013) & Prostate & Farming & 1 & $\mathrm{Y}$ & $x-2012$ & 12 & 0 & None \\
\hline Silva (2016) & Prostate & Pesticides & 3 & $\mathrm{Y}$ & $x-2015$ & 49 & 29 & NOS \\
\hline
\end{tabular}

NR Not reported, NHL Non-Hodgkin Lymphoma, NOS Newcastle Ottawa Scale, EPHPP effective public health practice project, *Based on a count of the studies, number not reported by the authors 
outcome (i.e. mortality vs. incidence), study design, and control for confounders (Depczynski and Lower 2014; Doolan et al. 2014; Lewis-Mikhael et al. 2016; Silva et al. 2016). The reviewers Lewis-Mikhael and colleagues evaluated 52 studies and stratified pooled estimates based on different quality-related aspects (Lewis-Mikhael et al. 2016). From this, the authors suggested that biases of exposure misclassification, using hospital controls and not controlling for family history of prostate cancer, may have led to higher risk estimates in selected studies. For example, in analyses stratified by exposure assessment quality (using the NOS), lower meta odds ratios were reported for studies with high quality (mOR 0.85; 95\% CI $0.57-1.14$ ) compared to studies with low quality (mOR 2.19 ; 95\% CI 1.38-3.00).

Another large systematic review by Silva et al. (2016) used the NOS tool to exclude one study for low quality. However, there was no further evaluation or discussion on aspects related to quality or bias. The authors pointed to the diversity in study populations, methodologies, and the putative role of family history of prostate cancer. Ntzani et al. (2013) approached their review by discussing the results of the AHS publications $(N=25,65 \%$ of the reviewed studies) for which the analyses were for specific pesticides. The discussion on the other studies pointed to observations of increased risk and for which study quality was moderate or low.

Several reviewers summarized the study finding based on occupation (farming/farm workers). Krestev and Knutsson reported a null meta relative risk (mRR 0.99; 95\% CI 0.95-1.02) (Krestev and Knutsson 2019) and Depczynski and Lower described the risk of prostate cancer among farmers as weak with many methodological inconsistencies (Depczynski and Lower 2014). In contrast, Ragin et al. (2013) reported a higher risk of prostate cancer among farmers, but an inverse relation for pesticide use (mOR $0.68 ; 95 \%$ $0.49-0.96)$.

\section{Non-Hodgkin lymphoma (NHL)}

The reviews with a focus on NHL and the authors' conclusions are shown in Table A2 in the Appendix. Similar to the reviews of prostate cancer, about half discussed the literature qualitatively while others used a quantitative approach of meta-analyses. There are research challenges related to the evolution of the diagnostic definition of lymphohematopoietic cancers, and NHL specifically. Several reviewers discussed these difficulties and the impact that reduced statistical power to study histological subtypes can present for epidemiologic research (e.g. (Alavanja et al. 2013; Schinasi and Leon 2014; von Stackelberg 2013)).

Alavanja et al. (2013) acknowledged that their review was not comprehensive and as such, only highlighted some inconsistencies in the literature. Ntzani et al. (2013) and Schinasi and Leon (2014) were more exhaustive on the number of studies identified and each took different approaches to evaluate the literature. Ntzani et al. (2013) discussed many results in the context of the AHS and did not focus on any specific pesticide. In contrast, Schinasi and Leon were quantitative in their review, stratifying their pooled analyses and discussion on specific active ingredients as well as providing discussion by gender, design, diagnosis period, and geographic area (Schinasi and Leon 2014).

$\mathrm{Hu}$ et al. and Schinasi and Leon, reported statistically significant associations with diazinon and NHL based upon seven and three studies, respectively (Hu et al. 2017; Schinasi and Leon 2014). Several reviews provided results on specific herbicides, such as atrazine (class triazine), with mixed conclusions (Boffetta et al. 2013; Sathiakumar et al. 2011; Schinasi and Leon 2014). For example, Schinasi and Leon, reported a significant mRR of 1.5 for triazine exposure (Schinasi and Leon 2014) while the larger narrative style reviews by Boffetta et al. and Sathiakumar et al. reported a lack of a consistent association (Boffetta et al. 2013; Sathiakumar et al. 2011).

\section{NHL reviews of 2,4-D}

The authors of three narrative style reviews of phenoxy herbicide 2,4-D and NHL discussed inconsistencies of results across studies (Burns and Swaen 2012; Jayakody et al. 2015; von Stackelberg 2013). Jayakody et al. (2015) highlighted the challenges inherent in evaluating uncommon exposures and uncommon outcomes. Von Stackelberg (2013) pointed to the concomitant use of different herbicides among applicators and farmers, while Burns and Swaen (2012) compared studies by statistical significance, evidence of a doseresponse, and consistency within and across studies.

Four other publications summarized the 2,4-D literature quantitatively, i.e. meta-analyses. As shown in Table A2, Schinasi and Leon (2014) and Smith et al. (2017) reported similar meta estimates of 1.4 and 1.3 for NHL and ever use of 2,4-D. In contrast, Goodman et al. $(2015,2017)$ reported no increased risk of 2,4-D and NHL among nine studies (mRR $=0.97,95 \%$ CI 0.77-1.22), nor when including unpublished AHS results (mRR 0.97, 95\% CI 0.79-1.18). These publications used different selection criteria that likely impacted the pooled result. For example, the metaanalyses by Smith and colleagues (2017) included two studies with specific diagnoses often excluded from reviews of NHL, B cell lymphoma, and hairy cell leukemia (Cocco et al. 2013; Nordstrom et al. 1998). Goodman et al. (2015) used the results from a 2011 publication from a Canadian study $(\mathrm{RR}=0.94)$ while Smith et al. (2017) elected to use the 2001 results from the same study $(R R=1.3)$. 


\section{NHL reviews of glyphosate}

There were four reviews of glyphosate and NHL studies in addition to the glyphosate-specific analyses of Schinasi and Leon (2014). Mink et al. (2012) discussed the limitations of self-reported exposure related to use of protective equipment and findings of biomonitoring studies. Acquavella et al. (2016) highlighted the potential for information bias among case-control studies. Both narrative reviews concluded there was no association between glyphosate and NHL.

The meta-analyses of Schinasi and Leon (2014), Chang and Delzell (2016) and Zhang et al. (2019) evaluated six glyphosate studies, reporting similar meta risk estimates but reaching different conclusions. Schinasi and Leon (2014) reported a statistically significant association of $1.5(95 \%$ CI 1.1-2.0) using univariate estimates. The pooled result from Chang and Delzell was slightly lower (1.3, 95\% CI 1.0 - 1.6) with no heterogeneity. Chang and Delzell discussed selection bias, exposure misclassification, and confounding. Using Bradford Hill principles, the authors concluded that the evidence was limited (Chang and Delzell 2016). Zhang et al. (2019) included an updated AHS analysis and pooled results using the highest exposure category resulting in a meta risk of 1.41 (95\% CI 1.13-1.75), concluding that results "were compelling."

\section{Results: toxicology}

In the current review of 30 publications, only nine involved some discussion of the animal toxicology literature for an active ingredient (e.g., permethrin, atrazine), with wide variation in the scope and depth of analysis. As shown in Table 2, some authors reviewed the toxicologic data at a high level, while others assessed the associations between pesticide exposure and cancer incidence in laboratory animals, notably with the discussion around mode/mechanism of action and exposure differential between animals and humans. Authors that included some review and discussion of animal carcinogenicity data were fairly consistent in providing definitive conclusions (Table 2) regarding the animal evidence and association with cancer types reported in epidemiologic studies. More specifically, Alavanja et al. (2013), Budnik et al. (2012), Goodman et al. (2015), Jowa et al. (2011), and Von Stackelberg (2013) all reported no evidence from animal studies or no basis for an association between exposure and cancer outcomes for the various specific pesticides they reviewed (Table 2). Boffetta et al. (2018) and Zhang et al. (2019) reported some evidence of tumorigenicity in animals following high exposure levels, which is not uncommon in standard regulatory toxicology testing as it is required that animal be exposed to a range of doses, including what is often termed a maximum tolerated dose. The salient point in such situations is to determine how relevant these exposures are, if at all, to human exposures. Finally, Lewis-Mikhael et al. (2016) and Smith et al. (2017) reported some basis in some test systems for additional investigation regarding carcinogenic outcomes but recommended that further mechanistic work be considered to determine relevance to humans, a point that we have raised earlier and which is now grounded in toxicology interpretation (i.e., the relevance of animal findings to humans).

The cancer assessments of IARC and the most recent United States Environmental Protection Agency (USEPA) Office of Pesticide Programs cancer risk assessment guidelines provide an in-depth evaluation of specific pesticides and cancer (EPA 2018; Rowland 2006; IARC 2020a). Numerous countries/organizations have similar review systems for carcinogenicity but for brevity, this paper only includes those of USEPA and IARC. Table 3 depicts examples of cancer or tumor type(s) that were associated with the respective active ingredient and then USEPA's and IARC's cancer classification for active ingredients based on required lifetime bioassays for evaluation of oncogenicity/cancer in laboratory rats and mice. Note there are differences in classification between the USEPA and IARC due to differing approaches, methods, and types of data reviewed.

Under USEPA classification, DDT and permethrin were classified as probable and likely carcinogens, respectively, while other pesticides were "suggestive, but not sufficient," "not likely" or "with evidence of non-carcinogenicity" based on rodent bioassay data. Additionally, the tumor types in these studies (i.e., liver primarily, although benign lung tumors in female mice exposed to permethrin) were dissimilar from the cancer type(s) reported in epidemiologic studies for these active ingredients (i.e., breast for DDT and multiple types other than liver for permethrin). In comparing across the reported epidemiologic associations between specific pesticide exposure and cancer types (Table 1) from the 30 papers reviewed, there is no animal concordance for the specific cancer/tumor types evaluated in the human studies. This may be due to robust testing requirements for cancer in laboratory animals which typically result in the ability to evaluate carcinogenic outcomes with little ambiguity. While there is no requirement to have site (i.e., same target tissue or organ) concordance when determining human carcinogenic risk from exposure, having site concordance in both animals and humans and then knowing the toxicological mode of action or adverse outcome pathway (i.e., assuming it is the same) for both would strengthen the evidence for an association in humans resulting from exposure. Conversely, if it is determined that the toxicological mode of action in animal studies is not operable or relevant to humans, then this informs the overall evaluation and resultant risk to humans. 


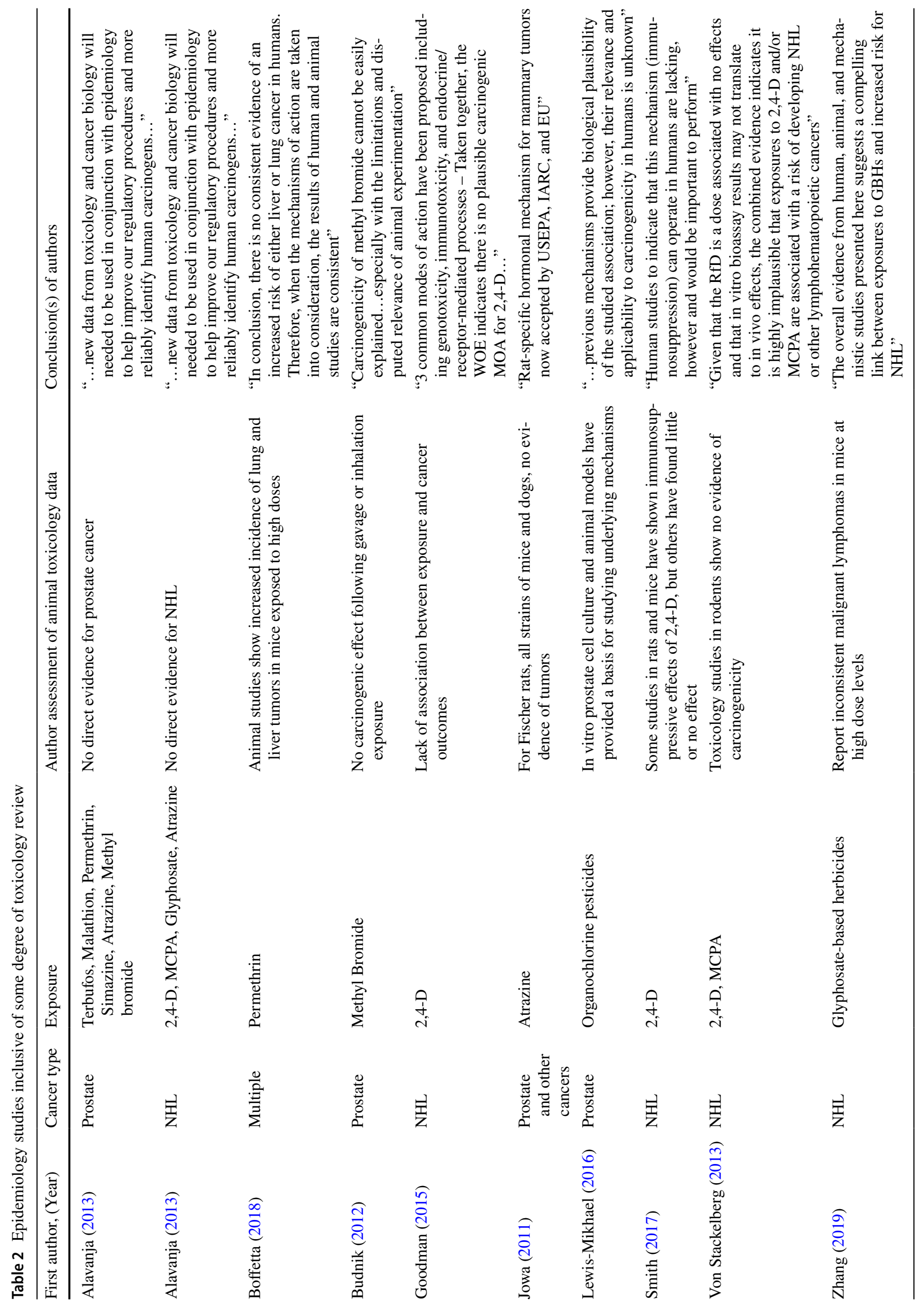


Table 3 USEPA/IARC cancer classification for active ingredients that have been associated with specific cancer types in epidemiologic studies

\begin{tabular}{lllll}
\hline Active ingredient & USEPA (EPA 2018; Rowland 2006) & $\begin{array}{l}\text { Tumor type and } \\
\text { animal species }\end{array}$ & $\begin{array}{l}\text { IARC } \\
\text { (2020a) }\end{array}$ & Cancer type (epidemiology) \\
\hline Lindane & Suggestive, but not sufficient & $\begin{array}{l}\text { Benign lung tumors (female mice } \\
\text { only) }\end{array}$ & 1 & NHL, prostate \\
DDT & B2-Probable & Liver-rat/mouse & 2A & Breast \\
Diazinon & Not Likely & Not applicable & 2A & NHL \\
Glyphosate & Not Likely & Not applicable & $2 \mathrm{~A}$ & NHL \\
Malathion & Suggestive, but not sufficient & Liver (mice), female rats at excessive & $2 \mathrm{~A}$ & NHL \\
& & doses & $2 B$ & Multiple, NHL, Prostate \\
2,4-D & D-not classifiable & Not applicable & 3 & Multiple, breast, prostate, NHL \\
Atrazine & Not likely & Neuroendocrine MOA & 3 & Prostate \\
Methyl Bromide & Not likely & Not applicable & Multiple \\
Permethrin & Likely & Lung (benign) in females and liver in & 3 & Multiple \\
MCPA & Not Likely & both sexes of CD1 mice & N/A & NHL \\
Terbufos & E- evidence of non-carcinogenicity & Not applicable & N/A
\end{tabular}

IARC Cancer Classifications (Group 1: Carcinogenic to humans; Group 2A: Probably carcinogenic to humans; Group 2B: Possibly carcinogenic to humans; Group 3: Not classifiable as to its carcinogenicity to humans), N/A not assessed

\section{Discussion}

The 30 reviews of epidemiologic studies of pesticides and cancer published in the last 10 years highlight the complexity of investigating the risk factors related to farming and other agricultural occupations. Cancers of the lung, breast, and colon were not frequently reviewed and none was associated with a specific pesticide. Prostate cancer and/or NHL were addressed in nearly half of the reviews. Authors reported mixed associations of prostate cancer related to farming and pesticides, in general, with some reviews showing positive associations with farming and not pesticides and vice versa (Krstev and Knutsson 2019; Lewis-Mikahel et al. 2016; Ragin et al. 2013).

Farming and prostate cancer has been a research focal point for many decades (Acquavella et al. 1998; Blair et al. 1992; Keller-Byrne et al. 1997; Van Maele-Fabry and Willems 2004). Generally, the reviews in the last decade characterized results of pesticides and prostate cancer as weak, inadequate, and/or limited to specific groups. For example, an increased risk of certain pesticides and prostate cancer has been reported among farmers with a family history of prostate cancer (Alavanja et al. 2003; Koutros et al. 2013a; Lewis-Mikhael et al. 2016; Silva et al. 2016). While this may reflect a shared environment, the unique nature of farming in which the occupation is passed down through generations and/or a gene-environment interaction, future researchers should consider this among other potential confounders (Koutros et al. 2013b). The findings of a link of prostate cancer with pesticides may be due to poor exposure assessment as suggested by Lewis-Mikhael and colleagues (2016).
Studies of specific active ingredients identified a possible association of prostate cancer and methyl bromide exposure but no association with 2,4-D, atrazine or organochlorines.

With respect to NHL, the reviews largely concluded a lack of an association for 2,4-D and atrazine. However, both positive and negative associations were reported for the herbicide glyphosate with reviewers reaching opposing conclusions (Acquavella et al. 2016; Chang and Delzell 2016; Mink et al. 2012; Schinasi and Leon 2014; Zhang et al. 2019). This is also seen among the IARC and governmental regulatory bodies such as the USEPA (Table 3). Potential biases within case-control studies and lack of genotoxic potential were discussed by Acquavella et al. and others (Acquavella et al. 2016; Williams et al. 2016). As discussed above, investigators in the future will be challenged to reduce these limitations to test the hypotheses generated by epidemiologic findings.

Several reviewers opted to use relative risk results for the highest exposed group in each study and incorporated these results into their pooled analysis (Hu et al. 2017; LewisMikhael et al. 2016; Smith et al. 2017; Zhang et al. 2019). While this approach may be seen to provide information in a worst-case scenario, the summary estimates derived are only meaningful for situations in which the underlying studies use homogeneous exposure categories. In the papers evaluated here, this was not always the case. For example, in the Smith meta-analysis for NHL and "highest" 2,4-D exposure, the exposure metric varied widely across the individual studies (Smith et al. 2017). The exposure proxy, "duration of use," was defined as seven days (McDuffie et al. 2001), 21 days (Zahm et al. 1990), five years (Burns et al. 
2011) and 10 years (Kogevinas et al. 1995) in four studies. However, these widely varying definitions of high exposure were considered to be equivalent in the meta-analysis. In other words, the reviewers created a risk estimate for "highly exposed groups" that implied a homogeneity that did not exist. Future reviews that seek to combine information from two or more studies would be strengthened if investigators utilized exposure categories that were concordant with those previously reported (Burns et al. 2019).

A review of the animal toxicology data for pesticides associated with cancer types in the epidemiologic reviews (i.e., in those reviews in which animal toxicity data were reviewed and discussed) indicated little biological plausibility or empirical data in support of an association between exposure and cancer in humans. Encouragingly, among those reviews which evaluated animal toxicology data, many discussed or recommended that advancements in toxicological research (e.g., mode of action) be considered or applied when evaluating epidemiological data -in this case relative to cancer association or causation in humans from pesticidal exposure. Alavanja, et al. recommended that "new data from toxicology and cancer biology will need to be used in conjunction with epidemiology to help improve our regulatory procedures and more reliably identify human carcinogens... "(Alavanja et al. 2013). In addition, it is notable that 6 of the 9 authors that reviewed toxicology data in conjunction with epidemiological data pointed to the consideration and use of mechanistic data on different levels (i.e., in vitro, receptormediated, in vivo animal) to assist in interpreting the relevance and applicability of animal data for humans (Table 2).

Evaluation and integration of data across the epidemiology and toxicology disciplines can be challenging (e.g. (Adami et al. 2011; Rhomberg 2015)), but it has been discussed within the scientific and regulatory communities as helpful in establishing biological plausibility and causal inference (Acquavella et al. 2003; Adami et al. 2011; Peklonen et al. 2019). Review organizations such as IARC and regulatory agencies compare and contrast existing animal toxicology data, including mode of action and its relevance to humans, in discussions involving associations between pesticide exposure and cancer outcomes in humans. This is important as (1) global regulatory bodies or organizations (i.e., USEPA, EFSA) are increasingly assessing both data streams (i.e., epidemiology and toxicology) for risk assessment and cancer classification and (2) contemporary knowledge on cancer biology and etiology continues to expand (Cohen et al. 2019; Doe et al. 2019; Wolf et al. 2019), which informs the ability to identify relationships between chemical exposure and association with cancer outcomes in humans. In addition, a particularly important consideration in the evaluation of reported human health outcomes from pesticide exposure is the exposure characterization across studies (i.e., animals and humans). While precise exposure estimates are rarely available in human research as they are in animal studies, efforts to quantify biomonitoring data in a risk-based context is informative. For example, urinary concentrations of 2,4-D among farmers and applicators have been shown to be lower than the regulatory reference dose (Aylward and Hays 2015). Acquavella, et al. recommended that epidemiologists consider the regulatory reference dose and No Observed Adverse Effect Levels (NOAEL) of pesticides when collecting exposure data (Acquavella et al. 2003). Epidemiologic research by job class and/or occupational group is hampered by the diversity of exposures to individuals. Going forward, investigators will need creative and novel approaches to better capture specific and multiple exposures, temporal changes, and use of personal protection equipment (Beane Freeman 2020). It is hoped that future epidemiologic investigations can improve and refine the quantification of exposure to facilitate data integration.

While humans are not rodents, it is advisable to evaluate the predictability and accuracy of rodent oncogenicity studies for humans. Animal testing affords insight into a chemical's carcinogenic potential, yields insight on the mode of action (or adverse outcome pathway) for that chemical, and informs on dose-response related to tumor response and how those exposures compare to human exposures. Animal models are not perfect predictors of toxicological or carcinogenic response in humans, but advancements in toxicology and exposure science have further progressed the ability to better predict outcomes in humans. Toxicological testing, evaluation and risk assessment programs such as those of the USEPA rigorously strive to protect human health by controlling and regulating human exposure to pesticides as mandated by law. These assessments and the subsequent limits on human exposure occur whether or not rodent tests show carcinogenic responses and the mode of action and exposures known to be associated with oncogenic response in rodents are relevant to humans (EPA 2002, 2005).

Relative to advancements in toxicology testing and how they are integrated into an overall approach for the protection of human health, including consideration of human epidemiologic studies, it has been proposed to move from the 2-year cancer bioassay in animals to a decision-tree matrix. The latter presumes that cancer is the consequence of DNA coding errors, arising from either direct mutagenic events or indirect sustained cellular proliferation (Cohen et al. 2019). Assessment of mutagenic (i.e., DNA reactive) activity through in vitro and in silico evaluations allows determination of mutagenic activity. If mutagenic, the chemical is assumed to be carcinogenic unless evidence indicates otherwise-if the chemical does not show mutagenic potential, an assessment of potential human exposure is compared to the threshold for toxicological concern. If anticipated exposure exceeds the threshold, then evaluations 
are conducted to look for key precursors to carcinogenicity such as increased cell proliferation, immunosuppression or significant estrogenic activity. Protection of human health is then approached by limiting exposure to below the established NOAELs for these precursor events. Moving forward, these advancements in toxicity testing, coupled with a novel and refined approaches for evaluating human exposures in epidemiologic studies, should afford more accurate and insightful learnings about associations between pesticide use and human disease, including cancer.

\section{Conclusion}

Just as cancer is not a unique disease, the exposures to "pesticides" and "farming" are similarly diverse. Interpretations are most informative when assessed by specific cancer type and active ingredients. However, it is a well-known challenge to collect these data reliably and validly with an adequate sample size, oftentimes retrospectively, all of which limits the ability to compare and contrast those exposures used in toxicology studies. For the last decade, there has been attention on the consideration, if not integration, of both animal and epidemiologic data for both risk assessment and regulatory decision-making [e.g. (Adami et al. 2011; Christensen et al. 2015)] and this remains a priority going forward. This review sought to compare the human and animal data relative to specific cancer outcomes reported in epidemiologic studies. While several pesticidal active ingredients were associated with specific cancer, overall, there was neither strong nor consistent epidemiologic data supportive of a positive association between pesticide exposure in occupational settings and cancer. In recent years, there have been progressive, science-based approaches for determining the oncogenic potential from chemicals, including pesticides, which include identification of genotoxic potential, toxicological mode of action, relevance to humans, and assessment of human exposure relative to doses used in animal experimentation. In addition, epidemiologic studies offer critical information and insight on exposure and disease, including cancer in humans. The challenge and opportunity at hand are for enhanced multidisciplinary collaboration to understand the contributions and limitations of both toxicologic and epidemiologic research so that underpinning scientific questions and informed study design will increase the ability and confidence to inform and protect human health.
Author contributions Both authors were involved in the conception, conduct, writing, and review of this manuscript.

Funding This work was supported by CropLife International (CLI). The views expressed in this manuscript are those of the authors and do not necessarily represent the views or policies of CLI. CLI was not involved in the design, collection, analysis and interpretation of data, nor in the writing of the manuscript, including the decision to submit it for publication. Note: "CropLife International is an international trade association of agrochemical companies founded in 2001. It was previously known as Global Crop Protection Federation and started out as the International Group of National Associations of Manufacturers of Agrochemical Products in 1967. Its members include the world's largest agricultural biotechnology and agricultural pesticide businesses namely BASF, Bayer CropScience, Corteva, FMC Corp., Sumitomo, and Syngenta." https://croplife.org/.

\section{Compliance with ethical standards}

Conflict of interest The authors are retired from The Dow Chemical Company (CJB) and Corteva AgriSciences (DRJ) that manufacture, formulate, and sell pesticides. Both currently consult to private industry.

Open Access This article is licensed under a Creative Commons Attribution 4.0 International License, which permits use, sharing, adaptation, distribution and reproduction in any medium or format, as long as you give appropriate credit to the original author(s) and the source, provide a link to the Creative Commons licence, and indicate if changes were made. The images or other third party material in this article are included in the article's Creative Commons licence, unless indicated otherwise in a credit line to the material. If material is not included in the article's Creative Commons licence and your intended use is not permitted by statutory regulation or exceeds the permitted use, you will need to obtain permission directly from the copyright holder. To view a copy of this licence, visit http://creativecommons.org/licenses/by/4.0/.

\section{References}

Acquavella J, Olsen G, Cole P, Ireland B, Kaneene J, Schuman S, Holden L (1998) Cancer among farmers: a meta-analysis. Ann Epidemiol 8(1):64-74. https://doi.org/10.1016/s1047 -2797(97)00120-8

Acquavella J, Doe J, Tomenson J, Chester G, Cowell J, Bloemen L (2003) Epidemiologic studies of occupational pesticide exposure and cancer: regulatory risk assessments and biologic plausibility. Ann Epidemiol 13(1):1-7. https://doi.org/10.1016/s1047 -2797(02)00423-4

Acquavella J, Garabrant D, Marsh G, Sorahan T, Weed DL (2016) Glyphosate epidemiology expert panel review: a weight of evidence systematic review of the relationship between glyphosate exposure and non-Hodgkin's lymphoma or multiple myeloma. Crit Rev Toxicol 46:28-43. https://doi.org/10.1080/10408 444.2016.1214681

Adami HO, Berry SC, Breckenridge CB, Smith LL, Swenberg JA, Trichopoulos D, Weiss NS, Pastoor TP (2011) Toxicology and epidemiology: improving the science with a framework for combining toxicological and epidemiological evidence to establish causal inference. Toxicol Sci 122(2):223-234. https://doi. org/10.1093/toxsci/kfr113 
Alavanja MC, Bonner MR (2012) Occupational pesticide exposures and cancer risk: a review. J Toxicol Environ Health B Crit Rev 15(4):238-263. https://doi.org/10.1080/10937404.2012.632358

Alavanja MC, Samanic C, Dosemeci M, Lubin J, Tarone R, Lynch CF, Knott C, Thomas K, Hoppin JA, Barker J, Coble J, Sandler DP, Blair A (2003) Use of agricultural pesticides and prostate cancer risk in the Agricultural Health Study cohort. Am J Epidemiol 157(9):800-814

Alavanja MC, Ross MK, Bonner MR (2013) Increased cancer burden among pesticide applicators and others due to pesticide exposure. CA Cancer J Clin 63(2):120-142. https://doi.org/10.3322/ caac. 21170

Alexander DD, Weed DL, Mink PJ, Mitchell ME (2012) A weight-ofevidence review of colorectal cancer in pesticide applicators: the Agricultural Health Study and other epidemiologic studies. Int Arch Occup Envir Health 85(7):715-745. https://doi.org/10.1007/ s00420-011-0723-7

Arnold M, Karim-Kos HE, Coebergh JW, Byrnes G, Antilla A, Ferlay J, Renehan AG, Forman D, Soerjomataram I (2015) Recent trends in incidence of five common cancers in 26 European countries since 1988: Analysis of the European Cancer Observatory. Eur J Cancer 51(9):1164-1187. https://doi.org/10.1016/j. ejca.2013.09.002

Aromataris E, Fernandez R, Godfrey CM, Holly C, Khalil H, Tungpunkom $P$ (2015) Summarizing systematic reviews: methodological development, conduct and reporting of an umbrella review approach. Int J Evid Based Healthc 13(3):132-140. https://doi. org/10.1097/XEB.0000000000000055

Aylward LL, Hays SM (2015) Interpreting biomonitoring data for 2,4-dichlorophenoxyacetic acid: Update to Biomonitoring Equivalents and population biomonitoring data. Regul Toxicol Pharmacol 73(3):765-769. https://doi.org/10.1016/j.yrtph.2015.11.001

Beane Freeman LE (2020) Challenges of pesticide exposure assessment in occupational studies of chronic diseases. Occup Environ MedOemed 2019:106348. https://doi.org/10.1136/oemed-2019106348

Blair A, Zahm SH, Pearce NE, Heineman EF, Fraumeni JF Jr (1992) Clues to cancer etiology from studies of farmers. Scand J Work Environ Health 18(4):209-215. https://doi.org/10.5271/sjweh .1578

Boffetta P, Desai V (2018) Exposure to permethrin and cancer risk: a systematic review. Crit Rev Toxicol 48(6):433-442. https://doi. org/10.1080/10408444.2018.1439449

Boffetta P, Adami HO, Berry C, Mandel JS (2013) Atrazine and cancer: a review of the epidemiologic evidence. Eur J Cancer Prev 22(2):169-180. https://doi.org/10.1097/CEJ.0b013e32835849ca

Budnik LT, Kloth S, Velasco-Garrido M, Baur X (2012) Prostate cancer and toxicity from critical use exemptions of methyl bromide: environmental protection helps protect against human health risks. Environ Health. https://doi.org/10.1186/1476-069x-11-5

Burns CJ, Swaen GM (2012) Review of 2,4-dichlorophenoxyacetic acid (2,4-D) biomonitoring and epidemiology. Crit Rev Toxicol 42(9):768-786. https://doi.org/10.3109/10408444.2012.710576

Burns C, Bodner K, Swaen G, Collins J, Beard K, Lee M (2011) Cancer incidence of 2,4-D production workers. Int J Environ Res Public Health 8(9):3579-3590. https://doi.org/10.3390/ijerph8093579

Burns CJ, LaKind JS, Mattison DR, Alcala CS, Branch F, Castillo J, Clark A, Clougherty JE, Darney SP, Erickson H, Goodman M, Greiner M, Jurek AM, Miller A, Rooney AA, Zidek A (2019) A matrix for bridging the epidemiology and risk assessment gap. Glob Epidemiol 1:100005. https://doi.org/10.1016/j.gloep i.2019.100005

Chang ET, Delzell E (2016) Systematic review and meta-analysis of glyphosate exposure and risk of lymphohematopoietic cancers. J Environ Sci Health B 51(6):402-428. https://doi. org/10.1080/03601234.2016.1142748

Christensen K, Christensen CH, Wright JM, Galizia A, Glenn BS, Scott CS, Mall JK, Bateson TF, Murphy PA, Cooper GS (2015) The use of epidemiology in risk assessment: challenges and opportunities. Hum Ecol Risk Assess Int J 21(6):1644-1663. https://doi. org/10.1080/10807039.2014.967039

Cocco P, Satta G, Dubois S, Pili C, Pilleri M, Zucca M, T'Mannetje AM, Becker N, Benavente Y, de Sanjosé S, Foretova L, Staines A, Maynadié M, Nieters A, Brennan P, Miligi L, Ennas MG, Boffetta P (2013) Lymphoma risk and occupational exposure to pesticides: results of the Epilymph study. Occup Environ Med 70(2):91-98. https://doi.org/10.1136/oemed-2012-100845

Cohen SM, Boobis AR, Dellarco VL, Doe JE, Fenner-Crisp PA, Moretto A, Pastoor TP, Schoeny RS, Seed JG, Wolf DC (2019) Chemical carcinogenicity revisited 3: risk assessment of carcinogenic potential based on the current state of knowledge of carcinogenesis in humans. Regul Toxicol Pharmacol 103:100-105. https://doi.org/10.1016/j.yrtph.2019.01.017

Depczynski J, Lower T (2014) A review of prostate cancer incidence and mortality studies of farmers and non-farmers, 2002-2013. Cancer Epidemiol 38(6):654-662. https://doi.org/10.1016/j.canep .2014.09.001

Doe JE, Boobis AR, Dellarco V, Fenner-Crisp PA, Moretto A, Pastoor TP, Schoeny RS, Seed JG, Wolf DC (2019) Chemical carcinogenicity revisited 2: current knowledge of carcinogenesis shows that categorization as a carcinogen or non-carcinogen is not scientifically credible. Regul Toxicol Pharmacol 103:124-129. https ://doi.org/10.1016/j.yrtph.2019.01.024

Doolan G, Benke G, Giles G (2014) An update on occupation and prostate cancer. Asian Pac J Cancer Prev 15(2):501-516. https:// doi.org/10.7314/apjcp.2014.15.2.501

EPA (2002) A review of the reference dose and reference concentration processes. vol EPA/630/P-02/002F. Washington, DC

EPA (2005) Guidelines for carcinogen risk assessment. Washington, D.C.

EPA (2018) Chemicals evaluated for carcinogenic potential annual cancer report 2018. US Environmental Protection Agency. http://npic. orst.edu/chemicals_evaluated.pdf. Accessed 5 May 2020

Goodman JE, Loftus CT, Zu K (2015) 2,4-Dichlorophenoxyacetic acid and non-Hodgkin's lymphoma, gastric cancer, and prostate cancer: meta-analyses of the published literature. Ann Epidemiol 25(8):626-636. https://doi.org/10.1016/j.annepidem.2015.04.002

Goodman JE, Loftus CT, Zu K (2017) 2,4-Dichlorophenoxyacetic acid and non-Hodgkin's lymphoma: results from the Agricultural Health Study and an updated meta-analysis. Ann Epidemiol 27(4):290-292.e295. https://doi.org/10.1016/j.annep idem.2017.01.008

Hu L, Luo D, Zhou T, Tao Y, Feng J, Mei S (2017) The association between non-Hodgkin lymphoma and organophosphate pesticides exposure: a meta-analysis. Environ Pollut (Barking, Essex: 1987) 231(Pt 1):319-328. https://doi.org/10.1016/j.envpol.2017.08.028

IARC (2017) Some organophosphate insecticides and herbicides iarc monographs on the evaluation of carcinogenic risks to humans volume 112. http://publications.iarc.fr/Book-And-Report-Series/ Iarc-Monographs-On-The-Identification-Of-Carcinogenic-Hazar ds-To-Humans/Some-Organophosphate-Insecticides-And-Herbi cides-2017. Accessed 10 Jan 2020

IARC (2018) DDT, Lindane, and 2,4-D IARC monographs on the evaluation of carcinogenic risks to humans volume 113. http:// publications.iarc.fr/550. Accessed 17 Apr 2020

IARC (2019) Pentachlorophenol and Some Related Compounds IARC monographs on the evaluation of carcinogenic risks to humans volume 117. http://publications.iarc.fr/574. Accessed 17 Apr 2020 
IARC (2020a) Agents classified by the monographs volumes 1-125. World Health Organization. https://monographs.iarc.fr. Accessed 1 Apr 2020

IARC (2020b) Estimated number of new cases in 2018, worldwide, both sexes, all ages. https://gco.iarc.fr/today/online-analysis-table . Accessed 20 Apr 2020

Jayakody N, Harris EC, Coggon D (2015) Phenoxy herbicides, softtissue sarcoma and non-Hodgkin lymphoma: a systematic review of evidence from cohort and case-control studies. Br Med Bull 114(1):75-94. https://doi.org/10.1093/bmb/ldv008

Jowa L, Howd R (2011) Should atrazine and related chlorotriazines be considered carcinogenic for human health risk assessment? J Environ Sci Health C Environ Carcinog Ecotoxicol Rev 29(2):91144. https://doi.org/10.1080/10590501.2011.577681

Keller-Byrne JE, Khuder SA, Schaub EA (1997) Meta-analyses of prostate cancer and farming. Am J Ind Med 31(5):580-586. https ://doi.org/10.1002/(sici)1097-0274(199705)31:5\%3c580::aidajim13\%3e3.0.co;2-v

Kogevinas M, Kauppinen T, Winkelmann R, Becher H, Bertazzi PA, Bueno-de-Mesquita HB, Coggon D, Green L, Johnson E, Littorin M (1995) Soft tissue sarcoma and non-Hodgkin's lymphoma in workers exposed to phenoxy herbicides, chlorophenols, and dioxins: two nested case-control studies. Epidemiol 6(4):396-402

Koutros S, Beane Freeman LE, Lubin JH, Heltshe SL, Andreotti G, Barry KH, DellaValle CT, Hoppin JA, Sandler DP, Lynch CF, Blair A, Alavanja MC (2013a) Risk of total and aggressive prostate cancer and pesticide use in the Agricultural Health Study. Am J Epidemiol 177(1):59-74. https://doi.org/10.1093/aje/kws225

Koutros S, Berndt SI, Hughes Barry K, Andreotti G, Hoppin JA, Sandler DP, Yeager M, Burdett LA, Yuenger J, Alavanja MC, Beane Freeman LE (2013b) Genetic susceptibility loci, pesticide exposure and prostate cancer risk. PLoS ONE 8(4):e58195. https ://doi.org/10.1371/journal.pone.0058195

Krstev S, Knutsson A (2019) Occupational risk factors for prostate cancer: a meta-analysis. J Cancer Prev 24(2):91-111. https://doi. org/10.15430/jcp.2019.24.2.91

Lewis-Mikhael AM, Olmedo-Requena R, Martinez-Ruiz V, BuenoCavanillas A, Jimenez-Moleon JJ (2015) Organochlorine pesticides and prostate cancer, Is there an association? A metaanalysis of epidemiological evidence. Cancer Causes Control 26(10):1375-1392. https://doi.org/10.1007/s10552-015-0643-z

Lewis-Mikhael AM, Bueno-Cavanillas A, Ofir Giron T, OlmedoRequena R, Delgado-Rodriguez M, Jimenez-Moleon JJ (2016) Occupational exposure to pesticides and prostate cancer: a systematic review and meta-analysis. Occup Environ Med 73(2):134144. https://doi.org/10.1136/oemed-2014-102692

McDuffie HH, Pahwa P, McLaughlin JR, Spinelli JJ, Fincham S, Dosman JA, Robson D, Skinnider LF, Choi NW (2001) NonHodgkin's lymphoma and specific pesticide exposures in men: cross-Canada study of pesticides and health. Cancer Epidemiol Biomarkers Prev 10(11):1155-1163

Mink PJ, Mandel JS, Sceurman BK, Lundin JI (2012) Epidemiologic studies of glyphosate and cancer: a review. Reg Toxicol Pharm 63(3):440-452. https://doi.org/10.1016/j.yrtph.2012.05.012

Moher D, Liberati A, Tetzlaff J, Altman DG, Group P (2009) Preferred reporting items for systematic reviews and meta-analyses: the PRISMA statement. J Clin Epidemiol 62(10):1006-1012. https ://doi.org/10.1016/j.jclinepi.2009.06.005

Nguyen THY, Bertin M, Bodin J, Fouquet N, Bonvallot N, Roquelaure Y (2018) Multiple exposures and coexposures to occupational hazards among agricultural workers: a systematic review of observational studies. Safety Health Work 9(3):239-248. https://doi. org/10.1016/j.shaw.2018.04.002

Nordström M, Hardell L, Magnuson A, Hagberg H, Rask-Andersen A (1998) Occupational exposures, animal exposure and smoking as risk factors for hairy cell leukaemia evaluated in a case-control study. Br J Cancer 77(11):2048-2052

Ntzani EE, Ntritsos G MC, Evangelou E, Tzoulaki I (2013) Literature review on epidemiological studies linking exposure to pesticides and health effects. EFSA Support Publ 10(10):159. https://doi. org/10.2903/sp.efsa.2013.EN-497

Oddone E, Modonesi C, Gatta G (2014) Occupational exposures and colorectal cancers: a quantitative overview of epidemiological evidence. World J Gastroenterol 20(35):12431-12444. https:// doi.org/10.3748/wjg.v20.i35.12431

Pelkonen O, Bennekou SH, Crivellente F, Terron A, Hernandez AF (2019) Integration of epidemiological findings with mechanistic evidence in regulatory pesticide risk assessment: EFSA experiences. Arch Toxicol 93(6):1779-1788. https://doi.org/10.1007/ s00204-019-02467-w

Ragin C, Davis-Reyes B, Tadesse H, Daniels D, Bunker CH, Jackson M, Ferguson TS, Patrick AL, Tulloch-Reid MK, Taioli E (2013) Farming, reported pesticide use, and prostate cancer. Am J Mens Health 7(2):102-109. https://doi.org/10.1177/1557988312458792

Rhomberg L (2015) Hypothesis-based weight of evidence: an approach to assessing causation and its application to regulatory toxicology. Risk Anal 35(6):1114-1124. https://doi.org/10.1111/risa.12206

Rowland J (2006) Chemicals evaluated for carcinogenic potential by the Office of Pesticide Programs. Office of Pesticide Programs, Washington, DC

Sathiakumar N, MacLennan PA, Mandel J, Delzell E (2011) A review of epidemiologic studies of triazine herbicides and cancer. Crit Rev Toxicol 41:1-34. https://doi.org/10.3109/10408 444.2011.554793

Schinasi L, Leon ME (2014) Non-Hodgkin lymphoma and occupational exposure to agricultural pesticide chemical groups and active ingredients: a systematic review and meta-analysis. Int J Environ Res Public Health 11(4):4449-4527. https://doi. org/10.3390/ijerph110404449

Shea BJ, Reeves BC, Wells G, Thuku M, Hamel C, Moran J, Moher D, Tugwell P, Welch V, Kristjansson E, Henry DA (2017) AMSTAR 2: a critical appraisal tool for systematic reviews that include randomised or non-randomised studies of healthcare interventions, or both. Br Med J 358:j4008. https://doi.org/10.1136/bmj.j4008

Silva JF, Mattos IE, Luz LL, Carmo CN, Aydos RD (2016) Exposure to pesticides and prostate cancer: systematic review of the literature. Rev Environ Health 31(3):311-327. https://doi.org/10.1515/reveh $-2016-0001$

Smith AM, Smith MT, La Merrill MA, Liaw J, Steinmaus C (2017) 2,4-dichlorophenoxyacetic acid (2,4-D) and risk of non-Hodgkin lymphoma: a meta-analysis accounting for exposure levels. Ann Epidemiol 27(4):281-289. https://doi.org/10.1016/j.annep idem.2017.03.003

Van Maele-Fabry G, Willems JL (2004) Prostate cancer among pesticide applicators: a meta-analysis. Int Arch Occup Environ Health 77(8):559-570. https://doi.org/10.1007/s00420-004-0548-8

von Stackelberg K (2013) A systematic review of carcinogenic outcomes and potential mechanisms from exposure to 2,4-D and MCPA in the environment. J Toxicol. https://doi. org $/ 10.1155 / 2013 / 371610$

Williams GM, Aardema M, Acquavella J, Berry SC, Brusick D, Burns MM, de Camargo JLV, Garabrant D, Greim HA, Kier LD, Kirkland DJ, Marsh G, Solomon KR, Sorahan T, Roberts A, Weed DL (2016) A review of the carcinogenic potential of glyphosate by four independent expert panels and comparison to the IARC assessment. Crit Rev Toxicol 46:3-20. https://doi. org/10.1080/10408444.2016.1214677

Wolf DC, Cohen SM, Boobis AR, Dellarco VL, Fenner-Crisp PA, Moretto A, Pastoor TP, Schoeny RS, Seed JG, Doe JE (2019) Chemical carcinogenicity revisited 1: a unified theory of carcinogenicity based on contemporary knowledge. Regul 
Toxicol Pharmacol 103:86-92. https://doi.org/10.1016/j.yrtph .2019.01.021

World Health Organization (2018) Cancer. https://www.who.int/newsroom/fact-sheets/detail/cancer. Accessed 17 Apr 2020.

Zahm SH, Weisenburger DD, Babbitt PA, Saal RC, Vaught JB, Cantor KP, Blair A (1990) A case-control study of non-Hodgkin's lymphoma and the herbicide 2,4-dichlorophenoxyacetic acid (2,4-D) in eastern Nebraska. Epidemiol 1(5):349-356

Zhang L, Rana I, Shaffer RM, Taioli E, Sheppard L (2019) Exposure to glyphosate-based herbicides and risk for non-Hodgkin lymphoma: a meta-analysis and supporting evidence. Mut Res Rev Mut Res 781:186-206. https://doi.org/10.1016/j.mrrev.2019.02.001

Publisher's Note Springer Nature remains neutral with regard to jurisdictional claims in published maps and institutional affiliations. 